Cuadernos de Historia Contemporánea

ISSN: 0214-400X

http://dx.doi.org/10.5209/CHCO.56267

\title{
El gentleman y el bárbaro. Masculinidad y civilización en el nacionalismo vasco (1893-1937)
}

\author{
Nerea Aresti
}

Recibido: 17 de octubre de 2016 / Aceptado: 23 de marzo de 2017

Resumen. Este artículo analiza la evolución de los ideales de masculinidad creados por el nacionalismo vasco desde sus orígenes, a finales del siglo XIX, hasta la guerra civil española, situando el concepto de civilización en el centro. El "hombre vasco" fue construido en oposición al español y se situó a sí mismo cercano a la figura del gentleman. El trabajo plantea que este juego de identificaciones y contrastes no fue una derivación lógica de la ideología nacionalista o de su comprensión del significado de la diferencia sexual. Al contrario, fue fruto de maniobras discursivas y redefiniciones que pusieron de manifiesto la versatilidad de los conceptos y su capacidad para adaptarse a visiones del mundo y proyectos políticos dispares.

Palabras clave: Masculinidades, nacionalismo vasco, civilización, género, gentleman.

[en] The Gentleman and the Barbarian. Masculinity and Civilization in Basque Nationalism (1893-1937)

\begin{abstract}
This article explores the evolution of the masculine ideals created by the Basque nationalism since its origins at the end of the $19^{\text {th }}$ Century until the Spanish civil war (1936-1939). The concept of civilization is at the center of this analysis. The "Basque man" was constructed in opposition to the Spanish man, being the gentleman a key reference in this construction. This play of identifications and contrasts was not the logical outcome of nationalist ideology and its visions of sexual difference. Far from that, what we can find is discursive maneuvers and redefinitions, which draw our attention to the versatility of concepts and to their capacity to adapt to different worldviews and political projects.

Keywords: Masculinities; Basque nationalism; Civilization; Gender, Gentleman.
\end{abstract}

Sumario. Introducción. 1. El nacionalismo vasco y el "anglosajonismo". 2. El gentleman vasco. 3. Reflexiones finales. La masculinidad de Andima.

Cómo citar: Aresti, N. (2017). "El gentleman y el bárbaro. Masculinidad y civilización en el nacionalismo vasco (1893-1937)”. Cuadernos de Historia Contemporánea, 39, 83-103.

1 El presente trabajo se inscribe dentro del Grupo de Investigación Universitaria de la UPV/EHU titulado: "La experiencia de la sociedad moderna en España, 1870-1990, GIU14/22 y el proyecto del MINECO código: HAR2012-37959-C02-01.

2 Universidad del País Vasco, UPV/EHU (España)

E-mail: nerea.aresti@ehu.eus 


\section{Introducción}

Civilización y género son dos conceptos que han estado íntimamente relacionados en el pasado y continúan estándolo en el presente ${ }^{3}$. En concreto, la posición de las mujeres en una sociedad ha sido entendida en diferentes momentos de la historia como un indicador del avance de los pueblos en el proceso de superación del estado de "barbarie". Ya en el siglo XVIII, los ilustrados vieron en la condición de las mujeres un "signo y medida de la civilización" y un criterio fundamental para enjuiciar el progreso social". A lo largo del siglo XIX, en muy diferentes contextos, pensadores y políticos defendieron que "del grado de civilización de cada pueblo resulta siempre el grado de importancia que la mujer goza en él"s. Como es sabido, también los defensores de la doctrina católica insistieron machaconamente en la que denominaron labor civilizatoria de la religión, que habría emancipado a las mujeres de una esclavitud milenaria. El propio nacionalismo vasco de preguerra, un movimiento de indudable signo católico, no fue una excepción en este sentido, y desde sus filas se alertó frente a la influencia de pueblos bárbaros e impíos que trataban a las mujeres con desconsideración, como un ser inferior y una esclava ${ }^{6}$. Pese a la persistente vigencia de esta conexión entre el nivel civilizatorio y el estatus de las mujeres, sin embargo, en la práctica el valor de la civilización ha estado más consistentemente unido a los hombres, nombrados legítimos representantes de la nación y responsables del grado de progreso alcanzado por ella ${ }^{7}$. De la firmeza de esta relación no se deriva que los significados de la civilización y de la hombría nacional hayan permanecido estables en el tiempo. Lejos de ello, ambas definiciones han sido objeto de constantes luchas políticas y discursivas en las que los distintos nacionalismos han perseguido la identificación victoriosa de su masculinidad nacional con el concepto de civilización. Como veremos, el nacionalismo vasco representa un claro ejemplo de este empeño.

Este trabajo es un análisis de la evolución de la masculinidad creada por el nacionalismo vasco desde sus orígenes a finales del siglo XIX hasta la guerra civil española, desde una perspectiva que sitúa el concepto de civilización en el centro ${ }^{8}$. El "hombre vasco" fue construido simbólica y políticamente en oposición al considerado incivilizado hombre español y aspiró a colocarse, por otro lado, cercano a la figura del gentleman. Este juego de identificaciones y contrastes no fue una derivación lógica de la ideología nacionalista o de su modo de entender el significado de la diferencia sexual. Bien al contrario, en los momentos fundacionales, la distancia

3 El estatus de las mujeres como termómetro de civilización es utilizado también hoy en día como argumento político en los conflictos internacionales. Así, por ejemplo, en el intento de legitimación de la invasión de Afganistán, Laura Bush apuntaba a la situación de las mujeres afganas como prueba del "barbarismo" que amenazaba al mundo civilizado. En Towns, Ann: "The Status of Women as a Standard of 'Civilization"”, European Journal of International Relations, 15-4 (2009), pp. 681-706, en p. 682 [DOI: 10.1177/1354066109345053].

4 Bolufer, Mónica: "Civilización, costumbres y política en la literatura de viajes a España en el siglo XVIII", Estudis, 29 (2003), pp. 255-300, en pp. 276-7.

5 Sorensen, Diana (ed.): Domingo Faustino Sarmiento: Obras selectas. Facundo. Recuerdos de provincia, ensayos y discursos. Viajes por Europa, África y América, Madrid, Espasa, 2002, p. 185.

6 Gallastegui, Elías: Por la libertad vasca, Bilbao, E. Verdes, 1933, tomo I, p. 124.

7 De hecho, hasta cierto punto, la posición de las mujeres como termómetro del grado de civilización de un pueblo conlleva una valoración del modelo de masculinidad asociado a ese estatus.

8 Los estudios históricos de las masculinidades y su relación con los nacionalismos han tenido un desarrollo significativo en los últimos años, incipiente en el caso de nuestro contexto académico (ver la presentación a este dossier). 
entre el ruralismo tradicionalista de Sabino Arana y los valores representados por la civilización inglesa fue superada por maniobras discursivas que pusieron de manifiesto la versatilidad de los conceptos y su capacidad para adaptarse a visiones del mundo y proyectos políticos dispares. Posteriormente, esa contradicción fue menos acusada en la medida en que ciertos sectores del nacionalismo vasco se fueron reconciliando con el fenómeno urbano y los valores de la civilización moderna.

\section{EI nacionalismo vasco y el "anglosajonismo"}

Entre muchos nacionalistas vascos de preguerra, los pueblos anglófonos fueron considerados como vanguardia de progreso y ejemplo a seguir por los pueblos que, como el vasco, estarían aún construyendo su propio camino. En 1918, Ramón de Belaustegigoitia, en un artículo con el significativo título "La hegemonía anglosajona y nosotros", planteaba la cuestión del modo siguiente:

La base está en lo popular, pero lo popular necesita guías... Y aquí del anglosajonismo. No necesitamos imitar ni copiar, sino descopiar y desimitar. Pero sí guías, guías espirituales por donde encauzar nuestra personalidad, guías en muchas materias desde el estudiar hasta el legislar, juzgar, producir o colonizar. Necesitamos maestros que den cierta norma hasta que llegue el momento que las hagamos nosotros mismos?.

Para Belaustegigoitia, Euzkadi se encontraba entonces ante una disyuntiva. Podía mirar hacia un sur decadente y pesimista, del que él creía que el pueblo vasco debía despegarse si quería ser él mismo, o podía dirigir la mirada hacia el mar, hacia una civilización nueva, optimista, amante de la vida y de la acción ${ }^{10}$. El contraste creado entre estos dos referentes no era nuevo, sino que había venido estructurando los discursos del nacionalismo vasco sobre la masculinidad desde sus inicios.

El nacionalismo vasco nació a finales del siglo XIX, en un contexto de profundas transformaciones sociales. En aquellos años, un rápido proceso de industrialización había atraído grandes contingentes de mano de obra inmigrante, alterando el paisaje social, político y cultural de Bizkaia. Estos cambios generaron reacciones de rechazo y sentimientos de miedo por la pérdida de una identidad que se percibió amenazada. Sabino Arana, principal ideólogo del naciente nacionalismo vasco, concibió en este contexto un proyecto político, en palabras de José Luis de la Granja, "tradicionalista e integrista, antiliberal y antiespañol, antisocialista y antiindustrialista" ${ }^{\text {. Arana }}$

9 Belaustegigoitia, Ramón de: "La hegemonía anglosajona y nosotros. Parte II", Hermes. Revista del País Vasco, 29, 1918. En Hermes: Revista del País Vasco, Bilbao, Idatz Ekintza, D. L. (edición facsímil), 6 vols., vol. III, p. 15 .

10 Belaustegigoitia, Ramón de: “La hegemonía anglosajona y nosotros”, Hermes. Revista del País Vasco, $26,1918$. En Hermes: Revista del País Vasco..., II, p. 622. Otros colaboradores de Hermes eligieron como modelo a seguir el de Dinamarca. En Urabayen, Leoncio de: "Sobre la manera de aumentar el valor universal del pueblo vasco. Un país espejo para nosotros”, Hermes, 59, 1918. En Hermes: Revista del País Vasco..., IV, p. 295.

11 De la Granja, José Luis: El nacionalismo vasco: Un siglo de historia, Madrid, Tecnos, 1995, p. 14. Una caracterización cercana a la señalada, en De Pablo, Santiago y Mees, Ludger: El péndulo patriótico. Historia del Partido Nacionalista Vasco (1895-2005), Barcelona, Crítica, 2005, p. 16. 
planteó como objetivo la restauración de un "orden tradicional feliz"12 supuestamente destruido por el liberalismo y la industrialización. La doctrina aranista idealizó, en oposición a un presente envilecido, el pasado de una Bizkaia rural, independiente, racialmente no contaminada, ejemplo de rectitud moral y salvaguarda de los principios católicos. Pero a la vez, el proyecto nacionalista tuvo un carácter plenamente moderno, y supo dotarse de todos los mecanismos necesarios para la lucha política en la emergente sociedad de masas, ofreciendo además su propia visión de futuro. En palabras de José Javier Díaz Freire, la clave interpretativa del nacionalismo vasco residiría en que prometió un porvenir arcaico, de retorno, desde la compleja aspiración de "entroncar la modernidad en los moldes del pasado"13. Esta misma promesa marcó también las visiones de género de este primer nacionalismo.

El ideal de masculinidad fue, para Sabino Arana, un referente para el género humano cuyos valores solo podían ser alcanzados por las mujeres en la medida en que superaran su condición femenina. Desde una concepción rígidamente jerárquica de la diferencia sexual, la masculinidad era un estatus superior con respecto a un único código de virtudes ${ }^{14}$. A la vez, este modelo superior coincidía con la caracterización del hombre vasco, representante del pueblo vasco en su conjunto. Para perfilar este arquetipo, Arana construyó un "cuerpo vasco", una fisonomía moral y en menor medida física, cuyos atributos correspondían fielmente al mandato cristiano, con importantes influencias también del higienismo típico de la época. Se trataba de un cuerpo honorable en sus relaciones con los otros y con las mujeres; recto en sus costumbres y amante de la limpieza; honrado y respetuoso con la autoridad; reservado y pacífico ${ }^{15}$. En el conocido artículo “¿Qué somos?”, escrito por Sabino Arana en 1895, la descripción del vizcaíno correspondía a una construcción maniquea en la que los valores que este atesoraba, su carácter varonil, su laboriosidad, inteligencia y espíritu emprendedor, tenían su reverso en el tipo femenil, la pereza, la torpeza, la indolencia, pasividad y cobardía del hombre español, aquel que "nada emprende, a nada se atreve, para nada vale"16.

Desde el modelo de virilidad descrito fue posible, como veremos, establecer por un lado nexos directos con el ideal típicamente burgués asociado a los pueblos angloparlantes - un modelo que distaba mucho de la visión del mundo de Arana-, y a la vez realizar una crítica mordaz de la masculinidad española, que actuaría como "referente de negación-oposición", utilizando el concepto de Justo Beramendi, particularmente apropiado para el caso vasco ${ }^{17}$. Esta contraposición entre las mascu-

12 Elorza, Antonio: "El nacionalismo vasco: la invención de la tradición”, Manuscripts, 12, 1994, pp. 183-192, en p. 185.

13 Díaz Freire, José Javier: La República y el porvenir: culturas políticas en Vizcaya durante la Segunda República, San Sebastián-Donostia, Kriselu, 1993, pp. 223 y 225.

14 Aunque la misoginia fue una constante del pensamiento aranista, es posible que su propia experiencia matrimonial suavizara su visión de las mujeres. Aresti, Nerea: "De heroínas viriles a madres de la patria. Las mujeres y el nacionalismo vasco (1893-1937)", Historia y Política, 31 (2014), pp. 281-308, en p. 286.

15 Díaz Freire, José Javier: "El cuerpo de Aitor. Emoción y discurso en la creación de la comunidad nacional vasca", Historia Social, 40, 2001, pp. 79-96, en p. 85.

16 Arana, Sabino: “¿Qué somos?”, Bizkaitarra, 30 de junio de 1895, en Obras Completas de Arana Goiri 'tar Sabin -en adelante O.C.-, Donostia, Sendoa, 1980, tomo I, p. 627.

17 Beramendi, Justo G.: "El partido galleguista y poco más. Organización e ideologías del nacionalismo gallego en la II República", en Justo G. Beramendi y Ramón Máiz (comp.): Los nacionalismos en la España de la II República, Madrid, Siglo XXI, 1991, pp. 127-170, en p. 136. Ver también De la Granja, José Luis: "El Antimaquetismo: La visión de Sabino Arana sobre España y los españoles”, Norba. Revista de Historia, 19, 2006, pp. 191-203. 
linidades vasca y española fue realizada en un contexto político internacional especialmente propicio para el proyecto aranista. En 1894, a través de las páginas de Bizkaitarra, Sabino Arana se congratuló de que España fuera, en su expresión, "la nación más atrasada de Europa", "la irrisión del mundo entero":

A la verdad que si no tuviéramos el corazón entristecido al sentir la desgracia de nuestra Patria y ver nuestro escudo cubierto de luto, habríamos de reírnos de buena gana del estado de decadencia en que se encuentra España ${ }^{18}$.

Sabino Arana se sintió así en una posición cercana a los países que arremetían contra España, aspirando a ser reconocido en el mismo lado de la confrontación. Él profesó una gran admiración por los pueblos supuestamente más avanzados en el panorama internacional que estaban creando una fuerte retórica de inferiorización de las razas latinas. A pesar de no participar plenamente de los planteamientos del darwinismo social y de un racismo basado en razones científicas -su racismo tuvo un fundamento sobre todo moral y religioso-, Arana supo establecer vínculos discursivos para participar de la crítica a las razas consideradas decadentes o atrasadas, y hacerlo en nombre del progreso:

No sabemos qué tienen en la sangre ciertas razas que todo cuanto está en contacto con ellas degenera y se prostituye. Ejemplos de ello nos da en abundancia la historia del pueblo romano y la historia de las naciones que llevan en su sangre la sangre latina. Mientras en los Estados Unidos de América alcanzan las ciencias un grado tal de adelanto que causa asombro, la América latina cierra las puertas al progreso y las abre de par en par a todos los vicios ${ }^{19}$.

Resulta relevante en este sentido que, aunque Arana compartió con los discursos cientificistas y racistas de la época el desprecio por los pueblos latinos, desde su visión recelosa del progreso desconfió de la "raza blanca", a la que acusó de esclavizar a los pueblos y describió como "la más vandálica del mundo" 20 .

En realidad, Sabino Arana veía con ojos muy críticos un modelo de desarrollo y una prosperidad material que, pensaba, estaban haciendo peligrar las virtudes ancestrales de la raza. Por ello, el propio concepto de progreso fue cuestionado por el padre del nacionalismo vasco. La crítica de Arana a la idea de progreso se expresó de formas diversas, en ocasiones recurriendo al sarcasmo: "¿Qué es el progreso? La cevelización. ¿Qué es la cevelización? El progreso"21. Esta y otras formulaciones estaban destinadas a desautorizar un concepto de civilización que consideraba erróneo y redefinirlo en un sentido antiliberal. De hecho, el liberalismo aparecía unido, a los

18 Aarana, Sabino: "Efemérides Infaustas", Bizkaitarra, 21 de julio de 1894, O. C., tomo I, pp. 316 y 317.

19 Arana, Sabino: "Vocación de esclavos", El Correo Vasco, 25 de agosto de 1899, O. C., tomo III, p. 1778.

20 "Y ¡aun tendrá a las demás por razas inferiores!”, exclamó. En Arana, Sabino: “Magnífico!”, Baseŕitaŕa, 8 de junio de 1897, O. C., tomo II, p. 1303.

21 Arana, Sabino: "La cultura de Bilbao", Baseritaŕa, 22 de agosto de 1897, O. C., tomo II, p. 1387. A partir de 1898, Arana abandonaría su anticapitalismo y aprobaría la industrialización vizcaína como prueba de la superioridad del pueblo vasco. En Anguera, Pere; Beramendi, Justo y De la Granja, José Luis: La España de los nacionalismos y las autonomías, Madrid, Síntesis, 2001, pp. 86-87. En este sentido, continúa siendo de referencia la obra de Solozábal, Juan José: El primer nacionalismo vasco. Industrialismo y conciencia nacional, Madrid, Túcar, 1975, así como la de Corcuera, Javier: Orígenes, ideología y organización del nacionalismo vasco (18761904), Madrid, Siglo XXI, 1979. 
ojos de Arana, a todos los vicios de una moral sexual incivilizada: "¿Queréis conocer la moral del liberalismo? Revistad las cárceles, los garitos y los lupanares: siempre los hallaréis concurridos de liberales" 22 . Bilbao representó para él ese progreso y esa civilización reprobados. La ciudad era descrita por Arana como la terrible enemiga de Bizkaia desde su origen ${ }^{23}$ " "la inmunda villa" cuyo estómago encallecido era incapaz de sentir náuseas por un hedor al que estaba acostumbrada ${ }^{24}$. En el siguiente párrafo, escrito en 1899, en una reivindicación defensiva de la Bizkaia rural, Arana fundió su ataque al español con una apropiación del concepto de civilización que le permitió, además, una -inestable-alineación con los juicios dirigidos contra España desde el exterior:

Los vascos aquellos de costumbres morigeradas y de proverbial hombría de bien eran unos ignorantes, estaban sin civilizar; en cambio, los de hoy viven en continuo roce con lo extraño, los que usan navaja, los que blasfeman, los que cantan flamenco, ésos están civilizados... Civilizados con la espléndida civilización que los horteras, polizontes, mineros y demás sabios del país de pan y toros nos han regalado ${ }^{25}$.

Pese a las contradicciones, Arana fue firme en su deseo de aprovechar un escenario internacional acorde con sus ideas. No casualmente, intentó enviar en cierta ocasión un cablegrama de felicitación al presidente Theodore Roosevelt con motivo de la derrota española en Cuba, documento en el que enaltecía a los Estados Unidos por los valores que representaba: "Ejemplo de magnanimidad, de culto á justicia y libertad, -le decía- dan vuestros poderosos Estados, desconocido en historia, inimitable para potencias europeas, particularmente latinas" ${ }^{26}$. Era necesario protegerse de la influencia perniciosa de un pueblo, el español, que Arana consideraba, en sus propias palabras, afeminado y embrutecido a la vez ${ }^{27}$. A través de esta caracterización se planteaba una doble estrategia de desvalorización del español, feminizándolo por un lado, y reduciéndolo por otro a mera naturaleza, a una masculinidad brutal y no civilizada ${ }^{28}$. De este modo, opinaba Arana, se debían combatir los efectos de

\footnotetext{
Arana, Sabino: "La ceguera de los bizkaínos", Bizkaitarra, 30 de septiembre de 1894, O. C., tomo I, pp. 368.

Arana, Sabino: "Mártires de la patria", Baseritaŕa, 23 de mayo de 1897, O. C., tomo II, p. 1285, en nota.

Arana, Sabino: "Las fiestas euskaras", Baseritaŕa, 9 de mayo de 1897, O. C., tomo II, p. 1259.

Arana, Sabino: "Nuestro mal", El Correo Vasco, 17 de junio de 1899, O. C., tomo III, p. 1679.

26 Arana, Sabino: "A raíz del cablegrama a Roosvelt [sic]”, carta de Sabino Arana dirigida a Enrique Aresti y Torre, presidente de la Diputación de Vizcaya (2 de junio de 1902), reproducida en el apéndice documental de Antxustegui Igartua, Esteban: El Debate Nacionalista. Sabino Arana y sus herederos, Murcia, Universidad de Murcia, 2007, pp. 14-17. También estos países a la cabeza del supuesto progreso, los Estados Unidos, Alemania o Gran Bretaña, atravesaron por situaciones de redefinición de los valores característicos de la masculinidad nacional, es decir, experimentaron sus propias crisis de masculinidad nacional. Ver Charnon Deutsch, Lou: "Cartoons and the politics of masculinity in Spanish and American press during the war of 1898", Prisma Social, 13 (2014-2015), pp. 109-148, en pp. 114-115 y 120; y Archilés, Ferrán: "Piel moruna, piel imperial. Imperialismo, nación y género en la España de la Restauración (c. 1880 c. 1909)", Mélanges de la Casa de Velázquez, 42-2 (2012), pp. 37-54.

27 Arana, Sabino: "La ceguera de los bizkaínos", Bizkaitarra, 30 de septiembre de 1894, O. C., tomo I, pp. 365366.

28 Ver Aresti, Nerea: “A la nación por la masculinidad. Una mirada de género a la crisis del 98”, en Mary Nash (ed.): Feminidades y masculinidades. Arquetipos y prácticas de género, Madrid, Alianza Editorial, 2014, pp. 47-74. El modelo del "bruto", del hombre incivilizado reducido a naturaleza, podría encajar en el concepto de hipermasculinidad -en oposición al modelo hipomasculino, feminizado- como un "otro" frente al que se construye la masculinidad normativa. Si bien estos conceptos han sido fructíferamente utilizados en ámbitos como la sociología, desde el punto de vista histórico plantean en mi opinión más problemas que ventajas, al
} 
este contacto nocivo a través de una "regeneración" que, en el caso vasco, tenía un carácter político-social y, podríamos añadir, moral ${ }^{29}$ :

Ahora que tanto oímos sonar la palabra regeneración, hagámonos aplicación de esta palabreja a nosotros mismos los vascos: que para lo demás no nos incumbe. Necesitamos regenerarnos, y esto sólo podemos conseguirlo con el amor de la verdadera religión y de la única política conforme con nuestras tradiciones: JAUNGOIKUA ETA LAGI-ZAŔ ${ }^{30}$.

Pero a diferencia del pueblo español, en opinión de Arana, el vizcaíno no necesitaba para su regeneración "ni enterrar su carácter, por ser serio y formal el que tiene; ni olvidar su historia, siendo como es ella ejemplar; ni reformar unas costumbres que, por lo ordenadas, son admiración de propios y extraños"31.

El nacionalismo vasco y la retórica internacional destinada al enaltecimiento de las denominadas razas civilizadas, frente a las consideradas moribundas, compartieron algunos de los juicios dirigidos a los españoles y su supuestamente dudosa virilidad. En ambos, los toros, la taberna y el baile flamenco constituyeron la manifestación más expresiva de la "embrutecida" raza española. Asimismo, la navaja, compañera inseparable de la violencia gratuita y el crimen a traición, adquirió connotaciones parejas en unos y otros discursos. De este modo, decía Arana, mientras en las fiestas vizcaínas rara vez ocurrían riñas, en la romería española siempre se vería "brillar la traidora navaja y enrojecerse el suelo"32. Lo que él denominaba "roce con el maqueto", solo traía, además de impiedad, blasfemia e inmoralidad, un aumento de la criminalidad"33. De hecho, afirmaba, según la estadística, el noventa y cinco por ciento de los crímenes que se perpetraban en Bizkaya se debían a mano española, y buena parte de los restantes tenían como autor el vizcaíno españolizado ${ }^{34}$.

La actitud respetuosa hacia las mujeres y la fidelidad a la esposa eran también cualidades pretendidamente comunes en los pueblos considerados más civilizados y en el vasco. Frente al vizcaíno, "amante de su familia y su hogar", el español era descrito como frecuentemente adúltero y sin afección al hogar ${ }^{35}$. Por culpa de este último, las tabernas, espacio de vicio masculino y perdición de la familia obrera, habían inundado la ciudad de Bilbao. Donde no había fuentes para satisfacer la sed de oro, sentenció Arana, el número de tabernas era incontable ${ }^{36}$. La costumbre de la taberna habría sido introducida por el inmigrante y contagiada al hombre de campo vizcaíno, quien veía entonces como "honroso y euskaro estarse en la taberna hasta altas horas de la noche", "y la inocente neskatil [muchacha] advierte que es la cosa

fijar culturalmente el significado de la masculinidad y su relación con la naturaleza, la violencia y la sexualidad irrefrenada.

29 Arana, Sabino: "La unión es fuerza", El Correo Vasco, 8 de agosto de 1899, O. C., tomo III, p. 1759.

30 Arana, Sabino: “Degeneración y regeneración”, El Correo Vasco, 28 de julio de 1899, O. C., tomo III, p. 1733. "Joun-Goikua eta Lagi-zaŕa" significa "Dios y Ley vieja" en euskera.

31 Arana, Sabino: "Regeneración”, El Correo Vasco, 8 de junio de 1899, núm. 5, O. C., tomo III, p. 1673. Este artículo fue versionado en 1922 en la publicación Abeŕi, P. M., 18 de marzo de 1922, p. 2, bajo el mismo título "Regeneración".

32 Arana, Sabino: “¿Qué somos?”..., p. 628.

33 Arana, Sabino: "La peregrinación obrera", Bizkaitarra, 3 de marzo de 1894, O. C., tomo I, pp. 365-438.

34 Arana, Sabino; “¿Qué somos?”..., p. 628.

35 Arana, Sabino: “QQué somos?”..., p. 628.

36 Arana, Sabino: "La cultura de Bilbao", Baseritaŕa, 22 de agosto de 1897, O. C., tomo II, p. 1388. 
más natural del mundo y más euskara del mundo danzar, estrechamente abrazada, a un hombre a la luz de las estrellas". Las horribles consecuencias de estos "pagánicos" hábitos dejaban su evidencia en el registro de nacimientos nueve meses después ${ }^{37}$.

El protagonista masculino de la comedia escrita por Sabino Arana con título De fuera vendrá... representaría este prototipo de hombre español, sin escrúpulos, adúltero e irresponsable. El joven "de la patria del Cid", pretendiente de una muchacha vasca (protagonista ausente en la obra), respondía al modelo del Don Juan desaprensivo, mujeriego y sin respeto hacia el sagrado matrimonio. En contraste con el honrado joven vasco, el burgalés pretendiente de la joven era un ejemplo de impostura masculina. Quien se presentaba como un "bello sujeto" de apariencia intachable resultaba ser realmente "un halcón, un ave de rapiña con figura del cordero y un aparente beato, que unas veces es un gran pillo y otras un gran lerdo"38. El burgalés conseguiría engañar al amigo de la familia, Don Inocencio, y al padre de la muchacha, Don Cándido. Frente a los valores representados por este personaje, la masculinidad típicamente vasca estaba basada en la honestidad y en la lealtad, y de hecho, afirmaba Arana, mientras el vizcaíno era amante de la familia y el hogar, el adulterio era frecuente entre los españoles tanto en las clases elevadas como en las humildes ${ }^{39}$.

La doctrina nacionalista compartió así determinados rasgos con aquellos discursos que, en nombre del progreso y la modernidad, estaban en aquellos años alimentando visiones racistas de los pueblos latinos en el contexto internacional. Esta confluencia fue posible no como derivación lógica del pensamiento aranista, sino porque determinadas cualidades tomaban significados distintos según los contextos discursivos. El valor del trabajo, la iniciativa, el sentido práctico, la contención de los sentimientos en público, la responsabilidad familiar, la austeridad y la rectitud eran conceptos lo suficientemente amplios y versátiles como para revestirse de connotaciones positivas en culturas políticas muy distintas, y concretamente tanto dentro de los parámetros del primer nacionalismo vasco como desde una perspectiva liberal y cientificista ${ }^{40}$. Asimismo, valores como el de la castidad, que en la doctrina de Arana ocupaba un lugar privilegiado entre las virtudes -también- masculinas, tuvieron que buscar un forzado aliado en la moderación y el autocontrol característicos del aquel hombre moderno con el que pretendía identificarse. Fruto de ello, el primer nacionalismo vasco se construyó en un juego de identificaciones y contrastes que estuvo más relacionado con voluntades políticas y juegos de poder que con ninguna definición estable de los conceptos manejados.

37 Arana, Sabino: "Las fiestas euskaras", Baseritaŕa, 9 de mayo de 1897, O. C., tomo II, p. 1258.

38 Arana, Sabino (edición y estudio histórico de José Luis de la Granja): De fuera vendrá... Comedia en tres actos, San Sebastián-Donostia, Haranburu Editor, (1982) [1898], p. 109.

39 Arana, Sabino: “QQué somos?”..., p. 628.

40 Relatos como el que siguen fueron típicos en este tipo de literatura destinada a construir un carácter de la raza vascongada y sirvieron de apoyo a los discursos posteriores: "Difícilmente se le verá a un euskaro vender naranjas, ni santos de yeso por la calle, ni lustrar botines, ni tocando el organillo con ó sin mono, ni implorar la caridad pública, porque no se amolda su génio activo y emprendedor á estas ocupaciones". En Goñi, Francisco: “La raza vascongada. Rasgos principales de su carácter", Vasconia. Revista ilustrada, 28 (1894), p. 332. 


\section{El gentleman vasco}

Los años veinte y treinta del pasado siglo remiten a un escenario distinto al del primer nacionalismo vasco de Sabino Arana con sus visiones de género. De hecho, el proyecto político inicial evolucionó en un proceso con muy acusadas continuidades pero también con cambios significativos. La doctrina aranista mantuvo su autoridad prácticamente intacta y continuó siendo el referente incuestionable en las filas nacionalistas ${ }^{41}$, pero la existencia de diferentes corrientes en su seno obliga a matizar. Al relativo dinamismo interno debemos sumar la acusada inestabilidad de las relaciones de género que fue característica del periodo de entreguerras. Esta inestabilidad vino acompañada de vivísimos debates e importantes evoluciones tanto en el plano discursivo como en las prácticas sociales y políticas. Consecuencia de ambas circunstancias, internas y más generales, se produjo una incorporación, que podemos denominar "sexuada", de las mujeres al movimiento nacionalista $v^{2} \mathrm{co}^{42}$. A través de la exaltación de la "madre vasca" se pretendió luchar contra las que se consideraban peligrosas extravagancias modernas, la amenazadora corriente de cambio que, se decía, pretendía hacer desaparecer las diferencias entre hombres y mujeres. En expresión del líder nacionalista Engracio Arantzadi, Kizkitza, era necesario por ello incitar a las bellas hijas de la montaña a volver al hogar, a la vida tradicional de la raza, haciendo frente al riesgo de derrumbamiento moral del hogar vasco ${ }^{43}$.

Como tantas veces sucede, los cambios en los modelos de feminidad vinieron acompañados de paralelas transformaciones en los ideales de masculinidad. En ese sentido, la radicalización de la idea de la diferencia sexual y el énfasis en el papel de las madres en la construcción nacional se apoyaron y complementaron con una reformulación de la masculinidad patriótica. Esta evolución no comportó desde luego cambios drásticos porque estos ideales siguieron estando básicamente identificados con los principios religiosos y morales de la doctrina aranista. Las continuidades fueron por lo tanto la nota dominante, y el buen vasco siguió siendo, sobre todas las cosas, un buen católico. Pero algunos ingredientes del modelo lograron un protagonismo mayor al que habían tenido en el pasado. En concreto, la laboriosidad y el espíritu emprendedor, valores ya presentes en el pensamiento del fundador, adquirieron mayor centralidad, aunque este giro tuvo lógicamente un marcado sesgo de clase.

Así, en relación con los trabajadores, y como he estudiado en otra parte ${ }^{44}$, la evolución posibilitó la creación de un modelo de masculinidad obrera respetable frente

41 La figura de Sabino Arana convertida en símbolo y mito hasta nuestros días, centro de un debate político en el que ha sido venerada por unos y odiada por otros, ha sido objeto de numerosos estudios, entre los que destaco el reciente de De la Granja, José Luis: Angel o demonio: Sabino Arana. El patriarca del nacionalismo vasco, Madrid, Tecnos, 2015.

42 Aresti, Nerea: "De heroínas viriles...", pp. 291 y ss. La monografía de referencia sobre la organización femenina en el seno del nacionalismo vasco es la obra de Ugalde Solano, Mercedes: Mujeres y nacionalismo vasco. Génesis y desarrollo de Emakume Abertzale Batza (1906-1936), Bilbao, Universidad del País Vasco, 1993. Ver también, Llona, Miren: "Polixene Trabudua. Historia de vida de una dirigente del nacionalismo vasco en la Vizcaya de los años treinta", Historia Contemporánea, 21 (2000), pp. 459-484.

43 Kizkitza: "Jauregui. Por la mujer vasca", Euzkadi, 5 de febrero de 1930, p. 1. También en Ager-Osin, "Después del homenaje a la madre vasca. La mujer en casa y fuera", Euzkadi, 22 de febrero de 1933, p. 4 (citados en Aresti, Nerea, "De heroínas viriles...", p. 293).

44 Aresti, Nerea: "El langile respetable. Masculinidad, moral y trabajo en el nacionalismo vasco", en Nerea Aresti, Julia Brühne y Karin Peters (eds.): ¿La España Invertebrada? Masculinidad y Nación en los años de entreguerras, Granada, Comares, 2016, pp. 119-135. 
al socialismo y a la vilipendiada figura del "maqueto". El nacionalismo vasco se dotó de un proyecto sindical propio dirigido a hacer frente a su competencia política y, en 1911, a partir de la "Comisión Regional de Acción Social” del Partido Nacionalista Vasco, nació el sindicato Solidaridad de Obreros Vascos-Euzko Langilien Alkartasuna $(\mathrm{SOV})^{45}$. Se elaboraron así unos referentes para la construcción de una masculinidad obrera nacionalista, en un movimiento que no era uniforme desde el punto de vista social y económico. Como era de esperar, en este proyecto el modelo de trabajador vasco era un ejemplo de moralidad y respeto al mandato católico frente a los vicios comunes en otros pueblos, particularmente en el español. Es interesante que a pesar de la especificidad de las propuestas de los nacionalistas vascos, los males morales que plantearon perseguir no fueron muy diferentes a los combatidos por el sindicalismo de la época en general: la taberna, la prostitución y sus secuelas, el juego y los toros -en el caso de SOV, los toros adquirían un significado político especial-. En opinión de los nacionalistas, las cualidades de la raza ponían freno a todos estos vicios, haciendo del hombre trabajador vasco un ejemplo de moralidad.

Pero fueron otros sectores del movimiento nacionalista vasco, aquellos más ligados a la experiencia de género de la burguesía y las clases medias ilustradas, los que experimentaron más claramente los cambios de énfasis que resultan más relevantes desde la perspectiva elegida para este trabajo, es decir, en relación con el vínculo de la virilidad con el concepto de civilización y la figura del gentleman. En concreto, detendré mi atención en una corriente minoritaria pero reveladora, un círculo de jóvenes nacionalistas estructurado en torno a la revista Hermes ${ }^{46}$, expresión de un proyecto de nación heterodoxamente abierto y plural. Aunque no se trataba de un grupo uniforme, con excepción de uno de sus miembros, el revisionista Eduardo de Landeta, mantuvieron el común respeto de los nacionalistas vascos por la figura autorizada de Sabino Arana ${ }^{47}$. Pero aun desde el respeto, esta corriente logró superar ciertas contradicciones que el aranismo mantuvo con la idea de progreso y de civilización moderna. De hecho, algunos de los miembros de una generación heredera de la próspera burguesía vizcaína sostuvieron opiniones críticas con respecto a las líneas dominantes, tanto de la mayoritaria Comunión Nacionalista Vasca como de los más radicales de Aberri, rompiendo lazos con el integrismo católico y el conservadurismo de Sabino Arana ${ }^{48}$. Como veremos, las concepciones de género de este grupo de heterodoxos tuvieron además sólidas conexiones con los nuevos moralistas laicos que, en la España de los años veinte y treinta, y con Gregorio Marañón a la cabeza, estaban creando abundantes discursos dirigidos a una "reforma sexual", un proyecto de carácter a la vez renovador y profundamente prescriptivo.

45 Ver Mees, Ludger: Nacionalismo vasco, movimiento obrero y cuestión social (1903-1923), Bilbao, Fundación Sabino Arana, 1992.

46 La revista Hermes fue publicada entre 1917 y 1922. Con sede en la ciudad de Bilbao y dirigida por el malogrado Jesús de Sarría, destacó por su raro aperturismo, aportando nuevos aires al clima político reinante en el nacionalismo vasco.

47 De la Granja, José Luis: “Ángel o demonio. Sabino Arana como símbolo del nacionalismo vasco”, Memoria y Civilización, 15 (2012), pp. 133-150, en p. 135.

48 De la Granja, José Luis: El nacionalismo vasco: Un siglo de historia, Madrid, Tecnos, 1995, p. 95. Ambas corrientes, Comunidad Nacionalista y el PNV de Aberri, se reunificaron en la Asamblea de Bergara de 1930, reafirmando los presupuestos de la doctrina aranista y frustrando cualquier expectativa de evolución doctrinal significativa. Ver también de Mees, Ludger: "El nacionalismo vasco y España: reflexiones en torno a un largo desencuentro", Espacio, Tiempo y Forma, Serie V, Historia Contemporánea, 9, 1996, pp. 67-83, en pp. 74-75. 
El grupo que animó la iniciativa editorial de Hermes se sintió, en términos generales, especialmente próximo al pueblo inglés y al ideal de masculinidad que ellos identificaban con aquel país. Debemos tener en cuenta que una parte importante de las fortunas de la burguesía vasca había estado relacionada con el trato económico, minero e industrial, con Inglaterra, y este vínculo tuvo notables repercusiones también en los planos cultural y simbólico. Esta proximidad se reflejó incluso en el vocabulario, de modo que palabras en idioma inglés adornaron el lenguaje político de unos jóvenes que decían querer una Euskeria que tuviera, a imitación del pueblo inglés, "su self control, que es la raíz del self government" ${ }^{49}$. Este grupo compartió una idea que el escritor conservador bilbaíno Ramón de Basterra plasmó en las páginas de Hermes, -revista que dio la bienvenida a colaboradores de ideología bien diversa en un raro ejercicio de tolerancia- ${ }^{50}$. Basterra aseguró haber encontrado en Inglaterra el conjunto de normas morales y de conducta que necesitaban entonces: ley de respeto mutuo, gentileza, diario afeite, curiosidad intelectual, afabilidad urbana... Si el pueblo vasco, afirmó, era un ejemplo de cumplimiento de la ley católica, hacía falta un mayor empeño para ser también más independientes y libres, bien manerados y cultos. El trabajo, el deporte, la cultura, y determinada forma de gestionar el cuerpo y la estética fueron para ellos elementos centrales de un ideal masculino representado por la figura del gentleman ${ }^{51}$. Si el pueblo más admirable era aquel entre cuyos ciudadanos volaba el enjambre más copioso de leyes cumplidas, concluiría Basterra, era lógico que los bilbaínos se sintieran tan a gusto entre los ingleses ${ }^{52}$.

A continuación, nos acercaremos a la figura del gentleman vasco a través del ejemplo proporcionado por uno de los miembros del grupo de Hermes, Alejandro de la Sota. Nacido en Bilbao en 1891, Alejandro era hijo del empresario naviero Ramón de la Sota (quien fue miembro de la sociedad fuerista Euskalerria, que en 1898 se unificaría con el proyecto encabezado por Sabino Arana). Su figura nos remite a un ideal de masculinidad que convivió, como he señalado, con otras formas de ser hombre en el seno del nacionalismo vasco. El vínculo de la familia De la Sota con Inglaterra había venido siendo muy estrecho, y el padre de Alejandro llegó a ser distinguido con el título de Sir en 1921 por poner a disposición del almirantazgo inglés

49 Landeta, Eduardo de: Los errores del nacionalismo vasco y sus remedios. Conferencia leída en el Centro Vasco de Bilbao el día 5 de mayo de 1923, Bilbao, Imp. y Lib. de J. Santos, 1923, p. 22.

50 A pesar de que Ramón de Basterra tuvo un acercamiento al nacionalismo vasco en los años en la segunda década de siglo, su evolución ideológica a lo largo de la década de los veinte acabó situándolo próximo al fascismo. Ortega Gallarzagoitia, Elene: "Ramón de Basterra y su imagen de Bilbao", Bidebarrieta, 8 (2000), pp. 397-408, en pp. 400 y 404. De hecho, como ha señalado Antonio Duplá, el vasquismo que mostró en la revista Hermes nunca dejó de combinarse con un acendrado nacionalismo español. Señala el autor que en el debate en torno a la nación vasca, "del que Hermes es durante unos años escenario privilegiado, Basterra y, en general, los contertulios del Lion d'Or [la denominada Escuela Romana del Pirineo] se sitúan nítidamente en la corriente más españolista”. Dupla Ansuategui, Antonio. El clasicismo en el País Vasco: Ramón de Basterra, Vasconia. 24 (1996), pp. 81-100, en p. 92.

51 Es importante advertir que la imagen que los nacionalistas vascos tenían del ideal inglés de masculinidad no tuvo por qué corresponder exactamente con el modelo dominante en aquellos momentos en aquel país. Algo semejante sucedía con los Estados Unidos, cuyos ideales de género eran igualmente admirados por los nacionalistas vascos más allá de los cambios sufridos por este ideal en los últimos años del siglo XIX, desde una masculinidad definida estrictamente por el control racional y el imperio de la voluntad, a otra en la que la agresividad, la fuerza física y la sexualidad reivindicaban un lugar legítimo. En Bederman, Gail: Manliness \& Civilization: A Cultural History of Gender and Race in the United States, 1880-1917, Chicago, University of Chicago Press, 1995, pp. 18-19.

52 Basterra, Ramón de: “El ideal y Bilbao”, Hermes, 22 (1918), Hermes: Revista del País Vasco..., II, p. 498. 
parte de su flota ${ }^{53}$. El prestigio que otorgaba tal distinción en la sociedad bilbaína de la época no fue ajeno a la influencia de los estereotipos ingleses sobre los ideales de masculinidad y feminidad en estos sectores sociales. Los hijos de Ramón de la Sota, el propio Alejandro y sus hermanos Ramón y Manuel, fueron formados, al igual que otros jóvenes vascos de su generación, en universidades británicas ${ }^{54}$. Y Alejandro de la Sota encarnó algunos de los rasgos más característicos de un ideal masculino construido a la sombra del ejemplo inglés.

Alejandro de la Sota formaba parte de una generación de jóvenes de la burguesía vasca que aspiraba a servir a la "dignificación oportunísima de la clase de señoritos ricos" de la ciudad. A pesar de sus aires bohemios, ligados a una vocación más ligada a las letras y a las artes que a la actividad industrial, el joven De la Sota fue descrito por sus contemporáneos como:

Glorioso ejemplo de los que haciendo de su vida regalada algo más que profesión de vagos, de derrochadores de fortunas, de bebedores de wisky [sic] y de champaña, de protectores de ninfas y de escandalosos nocturnos, dedícanse, con amor y entusiasmos nobles y elevados, al culto de las artes, honrándolas y enalteciéndolas para el buen nombre de la villa ${ }^{55}$.

De hecho, una pieza clave del modelo de masculinidad adoptado por este sector del nacionalismo fue la laboriosidad. El amor al trabajo era percibido como virtud en los hombres y como seña de identidad de una nación próspera. Como aseguró el también colaborador de la revista Hermes Eduardo de Landeta, "es en el trabajo donde se forjan y donde han sido modeladas las naciones que en el equilibrio universal son respetadas por su potencialidad económica y cultural", por lo que se imponía realizar una llamada para inculcar en los hombres vascos el sentimiento de cumplimiento del deber ${ }^{56}$. El propio Alejandro de la Sota se preocupó por alejarse del modelo de hombre ocioso y vividor y, exceptuando los respetables círculos de sociabilidad masculina en los que él mismo se movía, aseguró aborrecer todas "las otras reuniones de 'hombres solos' degradantes del espíritu moral y faltos de gracia alguna" 57 . Frente a estos espacios indeseables, el deporte ofrecía en su opinión un marco de camaradería masculina que, aunque podía plantear ciertos riesgos de ambigüedad, apelaba a valores característicos de la masculinidad modélica.

Alejandro de la Sota fue un decidido promotor de los deportes. En su opinión, el deporte tenía un efecto civilizador, contribuyendo a inculcar en los jóvenes vascos los valores de sacrificio y cooperación en pro de un objetivo común. Él veía en la activi-

53 Cava Mesa, María Jesús: Alejandro de la Sota. Un dandy bilbaíno, Bilbao, Fundación Bilbo 700-III Milenium, 2006, p. 24. Como señala la autora, particularmente, desde la revista Hermes se afirmó el orgullo que suponía el que un vasco fuera homenajeado de aquel modo por un país que figuraba en las avanzadas de la civilización. Ver también en Hermes, 70 (1921), Hermes: Revista del País Vasco..., V, p. 314.

54 Alejandro de la Sota cursó estudios de arte y literatura en la Universidad de Oxford. Su hermano mayor Ramón realizó la carrera de ingeniería naval e hidráulica en el King’s College de Londres. Por su parte, Manuel, el menor de los tres, estudió Derecho en Salamanca y Cambridge, donde impartió docencia durante varios cursos académicos. Pero fue Ramón, futuro heredero, quien se hizo cargo de los negocios familiares desde la Primera Guerra Mundial. En Cava Mesa, María Jesús: Alejandro de la Sota..., p. 47.

55 Etxabe, Alfredo de: “Acerca del libro Divagaciones de un transeúnte”, Hermes, 59 (1920), Hermes: Revista del País Vasco..., IV, p. 334. Esta cita y la anterior.

56 Landeta, Eduardo de: Los errores del nacionalismo..., p. 26.

57 De la Sota, Alejandro: "Notas desde Londres", Hermes 60 (1920), Hermes: Revista del País Vasco..., IV, p. 467. 
dad deportiva un signo de los tiempos y un indicador del tipo de masculinidad aceptable en cada país. Así, señaló que desde "el punto de vista viril, creo que solamente es comparable con el rugby la vasquísima regata de traineras" ${ }^{58}$. Pero el fútbol despertó en él un interés particular frente a los deportes tradicionales vascos, más identificados con el medio rural. Si bien estos últimos gozaban de más adeptos en otras corrientes nacionalistas, Alejandro de la Sota vio en el fútbol un elemento central del proceso de construcción de la identidad nacionalista ${ }^{59}$. En concreto, el futbolista respondía con precisión al modelo de hombre civilizado y autocontrolado. El fútbol aludía a una codificación de la energía física, una sujeción de impulsos violentos a través de la disciplina y control, del sometimiento a unas reglas del juego ${ }^{60}$, y, algo importante, podía servir como mecanismo de afirmación de civilidad frente a lo español.

Alejandro de la Sota cultivó esta afición al fútbol durante sus estancias en Londres y, fruto de dicha experiencia, relacionó la introducción de esta práctica deportiva con el desarrollo de la ciudad, con el ejercicio de la ciudadanía, con la democracia y con el progreso. Para De la Sota, el deporte y la ciudadanía eran dos aspectos inseparables de la sociedad moderna, que unían en un "vínculo lleno de esperanzas" a los pueblos cultos. Eran tiempos en los que los deportes elitistas habían ido cediendo terreno a prácticas en las que primero las clases medias, y luego las populares, participaban de una naciente sociedad de masas ${ }^{61}$. En opinión de Alejandro de la Sota, el fútbol en Inglaterra había creado espacios democráticos e interclasistas, presididos por la auténtica clase media, que él calificaba de llana y modesta, verdadero "espinazo del pueblo inglés" ${ }^{62}$. De hecho, planteaba, no debía atemorizar a nadie todo lo que contribuyera a "democratizar humanamente a las masas", y el fútbol actuaba en ese sentido. El pueblo inglés, una vez más, servía de guía y ejemplo para los vascos y su ciudad más moderna, Bilbao. La capital vizcaína estaba acogiendo en aquellos años nuevos clubs de fútbol mientras marchaba "brioso en busca de sus grandes y singulares designios" $"$. La experiencia ciudadana del espectador futbolístico era compartida así por los pueblos inglés y vasco, y esta sintonía fue celebrada por Alejandro de la Sota a través de dos personajes conocidos en la capital vizcaína, el inglés Mister Pennywhistle y el bilbaíno Mendigorrieta, protagonistas de una expresiva escena de su libro Divagaciones que nos trae el foot-ball que tenía lugar en una jornada deportiva: "Juntos el inglés y el bilbaíno, codo con codo, cual dos corinthians de la 'mesa redonda', marchó la pareja hacia algún rincón prendido del numen ciudadano"64.

58 De la Sota, Alejandro: Divagaciones que nos trae el foot-ball, Bilbao, Edit. Vasca, 1932, p. 19.

59 No se trataba de un caso aislado, al contrario, la estrecha relación entre identidad nacional, género y deporte fue bastante común en la Europa de finales del siglo XIX y comienzos del XX. Un buen ejemplo es el papel desempeñado por el fútbol en la rehabilitación de la masculinidad irlandesa, proceso marcado por la creación de la Gaelic Athletic Association en 1884. En McDevitt, Patrick F.: "Muscular Catholicism: Nationalism, Masculinity and Gaelic Team Sports, 1884-1916”, Gender \& History, 9-2 (1997), pp. 162-284. Un interesante estudio sobre la construcción europea de una narrativa sobre la nacionalidad española a partir del fútbol en Quiroga, Alejandro: Football and National Identities in Spain. The Strange Death of Don Quixote, Basingtoke, Palgrave Macmillan, 2013; y del mismo autor, ver también "El deporte", en Javier Moreno Luzón y Xosé M. Núñez Seixas (eds.): Ser españoles. Imaginarios nacionalistas en el siglo XX, Barcelona, RBA, 2013, pp. 474-484.

60 McDevitt, Patrick F.: "Muscular Catholicism...", p. 268.

61 Otero Carvajal, Luis Enrique: "Ocio y deporte en el nacimiento de la sociedad de masas. La socialización del deporte como práctica y espectáculo en la España del primer tercio del siglo XX”, Cuadernos de Historia Contemporánea, 25 (2005), pp. 169-198.

62 De la Sota, Alejandro: Divagaciones que nos trae el foot-ball..., p. 5.

63 De la Sota, Alejandro: Divagaciones que nos trae el foot-ball..., p. 136 y p. 31 la cita anterior.

64 De la Sota, Alejandro: Divagaciones que nos trae el foot-ball..., p. 298. 
Al igual que el trabajo productivo, la cultura y el deporte, el trato respetuoso con las mujeres fue asimismo un símbolo de progreso y rasgo distintivo del gentleman. El hombre moderno debía ser respetuoso y seductor a la vez. Alejandro de la Sota fue considerado entonces, y su reputación perduró en el tiempo, un atractivo dandy. De la Sota afirmó que "a Bilbao nunca le ha faltado su $d a n d y$ "65, y él mismo quiso representar este papel durante décadas. La figura del dandy había sido fruto del proyecto de crear una nueva estética para una nueva identidad, la identidad del nuevo caballero urbano, modelo de masculinidad burguesa. De hecho, el fin de siglo había sido "rico en artefactos culturales que giran en torno a la figura del dandy, bien porque se dirigen a él o porque le usan como ejemplo de distinción y modelo a seguir por los demás" ${ }^{\prime 6}$. La identidad del dandy fue construida tanto en el ámbito privado como en el público, o mejor, a través de una determinada relación de ambos. En este sentido también, el individualismo asociado al arquetipo masculino inglés dio alas a los hijos de la burguesía vasca pujante.

Alejandro de la Sota volvió de Londres a Bilbao, según escribió su amigo Joaquín de Zuazagoitia, "con su secreta erudición y con un gabán verde rabioso que acentuaba su aire de dandy despreocupado. Y así, ocultando su idiosincrasia bajo el verde gabán, empezó a pasear por la villa un poco zumbón y un poco melancólico" 67 . La publicación en 1920 de su libro Divagaciones de un transeúnte fue celebrada en los círculos más selectos de la capital y fue objeto de un acto de homenaje por la revista Hermes en el emblemático Club Marítimo del Abra ${ }^{68}$. El escritor Alfredo de Etxabe aseguró que el libro había sido escrito con una melancolía "impregnada por las neblinas del Támesis", "con la cultura de una educación esmeradísima, con el más depurado gusto, con limpieza impecable y dentro del regocijante humour de los finos escritores británicos, de su predilección e influencia" ${ }^{69}$. Su posición de observador externo, "como extranjero en su propia patria", le habría permitido imprimir su subjetividad sobre su objeto de contemplación con autoridad, porque, como aseguraba Eugenio D’Ors desde las páginas de Hermes, "el primer deber del paisajista es no formar parte del paisaje". Aquel "chimbo britanizado", dotado de "mirada inteligentísima, viva y penetrante", dandy portador de virtudes cívicas y gallardo exponente de su generación, fue comparado en su ambiente social con Guillaume Apollinaire y con el catalán Josep María Junoy ${ }^{70}$. Incluso Havelock Ellis dedicó unos elogios al librillo de bosquejos desde otra publicación de la época, la revista ilustrada La Baskonia ${ }^{71}$. Como ha señalado Joseba Agirreazkuenaga, Alejandro de la Sota contribuyó con su libro a la renovación de la "mitología bilbaína, fomentando un nuevo imaginario de la ciudad"

65 De la Sota, Alejandro: Divagaciones de un transeúnte, Bilbao, Editorial Vasca, 1920, p. 193.

66 Álvarez-García, José Ignacio: "Masculinidad como espectáculo: Modernidad y consumismo en España (18981931), tesis doctoral, University of Illinois, Urbana-Champaign, 2008. Capítulo titulado “¿El Paraíso del dan$d y$ ? Consumo y decadencia en el fin de siglo español", pp. 36-115, en p. 43.

67 Zuazagoitia, Joaquín de, prólogo a Alejandro De la Sota: Divagaciones de un transeúnte, Bilbao, Editorial Vasca, 1920, p. 10. Sobre la melancolía como emoción característica de la experiencia de la modernidad a través del escritor también bilbaíno Miguel de Unamuno, Díaz Freire, José Javier: "Miguel de Unamuno y Bilbao: la experiencia melancólica de la modernidad", Ayer, 98 (2015), pp. 21-44.

68 Agirreazkuenaga, Joseba: Hermes. Revista del País Vasco..., p. 85.

69 Etxabe, Alfredo de: "Acerca del libro Divagaciones de un transeúnte", Hermes, 59, 1920, Hermes: Revista del País Vasco..., IV, p. 334.

70 Xenius (Eugenio D’Ors): “Sobre Divagaciones de un transeúnte”, Hermes 66 (1920), Hermes: Revista del País Vasco..., V, p. 173. Cita anterior en p. 172.

71 Ellis, Havelock: "El genio de los baskos", La Baskonia. Revista Ilustrada, 10 de noviembre de 1920, p. 56.

72 Agirreazkuenaga, Joseba: Hermes. Revista del País Vasco..., p. 85. 
Modernidad, cosmopolitismo y valores ciudadanos se dieron cita en el joven Alejandro. Este modelo viril coincidía solo en parte, sin embargo, con el gentleman autocontrolado y austero. De hecho, la figura del $d a n d y$, con la que Alejandro de la Sota fue y sigue siendo hoy en día identificado, era una expresión demasiado sesgada de este ideal. La elegancia, el refinamiento, las buenas maneras, la educación exquisita o la sensibilidad artística podían encajar con este arquetipo masculino, sobre todo teniendo en cuenta que se trataba de un hombre joven. Pero la excesiva preocupación por el aspecto externo, el artificio, cierta ligereza moral y una relación cercana a la frivolidad con las mujeres habrían resultado más problemáticos. Debemos tener en cuenta que la artificialización del ser por el dandismo podía relacionarse con un desprecio de lo natural ${ }^{73}$ desestabilizador del fundamento pretendidamente inalterable de la diferencia sexual. Por eso, esta figura del dandy ha sido en ocasiones problematizada como modelo masculino. Históricamente, de hecho, la acusación de dandismo ha sido utilizada en el ámbito político para cuestionar la hombría y con ello desacreditar la imagen de destacados dirigentes ${ }^{74}$. Es necesario señalar sin embargo que en el caso de Alejandro de la Sota esta dimensión equívoca del dandismo no afectó en absoluto a su masculinidad, al contrario, fue asociada a un refinamiento característico del hombre civilizado que servía de contrapunto a la naturaleza incontenida y a la barbarie.

En esta misma línea, frente al ruralismo arcaizante de Sabino Arana, Alejandro de la Sota y el grupo en torno a Hermes se sintieron próximos a la cultura urbana peculiarmente representada por la figura del flâneur ${ }^{75}$. De la Sota se consideraba a sí mismo un "transeúnte sportivamente ciudadano" ". Tras su estancia en Inglaterra, el joven recorrió las calles de Bilbao y dibujó con palabras aquel paisaje inestable, aportando certidumbre a un escenario inquietante, apropiándose de las cosas "con sus ojos y sus oídos", es decir, "de la manera más noble y desinteresada", en palabras de Joaquín de Zuazagoitia en el laudatorio prólogo de Divagaciones de un transeúnte ${ }^{77}$. El espectador urbano aparecía como un símbolo del hombre moderno, el sujeto centrado que, desde una posición privilegiada, contemplaba la ciudad apropiándose de ella con mirada penetrante. A través de su mirada, el flâneur ordenaba discursivamente el caos de la ciudad y confería legibilidad al espacio urbano por medio de la "retórica del paseo"78.

73 Clúa, Isabel: “Género, cuerpo, performatividad”, en Mary Torras (ed.): Cuerpo e identidad. Estudios de género y sexualidad, Barcelona, Ediciones UAB, 2007, pp. 181-217, en p. 196. La autora realiza un acercamiento a la figura del dandy desde un punto de vista de género, planteando su relación ambigua con el poder, atribuyéndole un efecto político que consiste en una desnaturalización del sujeto que pone en evidencia la convencionalidad de las normas identitarias. En p. 195.

74 Theodore Roosevelt, por ejemplo, sufrió tales ataques en los primeros pasos de su carrera política antes de convertirse, a través de un proyecto de reinvención de sí mismo, en prototipo nacional de "masculinidad imperialista". En Nagel, Joane: "Masculinity and nationalism: gender and sexuality in the making of nations", Ethnic and Racial Studies 21/2 (1998), pp. 242-269, pp. 249-250. Ver también Bederman, Gail: Manliness \& Civilization: A Cultural History of Gender and Race in the United States, 1880-1917, Chicago, University of Chicago Press, 1995, p. 170

75 Esta figura ha sido analizada de forma magistral para el caso del Londres victoriano por Walkowitz, Judith R.: City of Dreadful Delight. Narratives of Sexual Danger in Late-Victorian London, Chicago, The University of Chicago Press, 1992. Ver en concreto las pp. 16 y 17. Y, como se sabe, este fue uno de los temas más celebrados de "El país del Segundo Imperio en Baudelaire" de Benjamin, Walter: Poesía y capitalismo, Madrid, Taurus, 1981, pp. 49-84.

76 De la Sota, Alejandro: Divagaciones que nos trae el foot-ball..., pp. 286 y 287.

77 Zuazagoitia, Joaquín de, prólogo a Alejandro De la Sota, Divagaciones de un transeúnte...,p. 15.

78 Cuvardic García, Dorde: "La reflexión sobre el flâneur y la flanerie en los escritores modernistas latinoamericanos", Káñina. Revista de Artes y Letras, 23/1 (2009), pp. 21-35, en pp. 21 y 22. 
Lo que acercaba Alejandro de la Sota a la figura del flâneur no eran ciertamente las dimensiones de la ciudad de Bilbao, pequeña villa ajena a la magnitud de las grandes urbes, sino la experiencia de la transformación drástica del espacio desde una determinada posición de sujeto. La actitud de Alejandro de la Sota respondía al afán de dominar la ciudad como escenario cambiante e inestable, de recomponer la fisonomía del paisaje de acuerdo a una nueva racionalidad, conjurando unos peligros inquietantes para las clases acomodadas. No casualmente, Alejandro de la Sota confesó preferir "vagar por ciertas pequeñas calles con fisonomía de alma urbanamente desordenada" que deambular por las modernas avenidas en cuyo ambiente se infiltraba un cosmopolitismo burgués ${ }^{79}$. Bajo la mirada del flâneur, lo extraordinario se convertía en un asunto doméstico ${ }^{80} \mathrm{y}$, en esta domesticación del espacio, el transeúnte se sentía "como en casa entre fachadas, igual que el burgués en sus cuatro paredes" $"$.

El libro Divagaciones de un transeúnte vino presidido por un grabado del pintor Aurelio Arteta titulado "La modistilla idealizada", una figura convertida en icono de un Bilbao moderno, de progreso, orgulloso de sus puentes y de su tranvía, el primero eléctrico de España. El dominio de la ciudad por la mirada de Alejandro de la Sota estuvo expresado desde el punto de vista de género -y con un fuerte componente de clase a su vez- a través de su relación con las "modistillas". De la Sota colaboró en la romantización del trato del señorito con las muchachas costureras estableciendo un problemático nexo entre las figuras del dandy y el donjuán. La capacidad de las "modistillas" para crear ambigüedad sobre su posición social y desafiar en ciertos aspectos las diferencias de clase ${ }^{82}$ hizo de ellas una figura de connotaciones complejas, un símbolo de la frontera con lo prohibido, de la línea de separación entre la señorita pudorosa y la mujer del pueblo, la mujer sexual ${ }^{83}$. En la otra cara de la moneda, sus aspiraciones de ascenso social hacían a las "modistillas" particularmente vulnerables frente al riesgo de abandono en una sociedad rígida e intolerante con este tipo de estrategias matrimoniales ${ }^{84}$. De la Sota, "joven apuesto y de aires seductores" ${ }^{85}$ no ahorró en alabanzas a la hora de describir "a estas chicas que desde tantos puntos de vista alcanzarían el nombre de señoritas fuera de su pueblo" $"$. A la vez, el autor reconoció que "la costurera es víctima de la persecución constante del señorito" práctica que alabó y que él mismo describió de forma pormenorizada, en primera persona, en más de una ocasión.

79 De la Sota, Alejandro: Divagaciones que nos trae el foot-ball..., p. 136.

80 Carrera Álvarez, Pilar: Walter Benjamin: El paseante y la ciudad, tesis doctoral, Universidad del País VascoEuskal Herriko Unibertsitatea, 2004, p. 158.

81 Benjamin, Walter: Iluminaciones II. Boudelaire. Un poeta en el esplendor del capitalismo (prólogo y traducción de Jesús Aguirre), Madrid, Taurus, 1972, p. 51.

82 Aseguraba Alejandro de la Sota que, conociendo él sus vidas al detalle, se podía decir "que estas chicas visten así de milagro". De la Sota, Alejandro: Divagaciones de un transeúnte..., p. 42.

83 Esta cuestión ha sido analizada en profundidad por Llona, Miren: "La realidad de un mito: la aspiración de ascenso social de las modistillas en el Bilbao de los años veinte y treinta", Asparkia. Investigació Feminista 14 (2004), pp. 139-167. Ver también, de la misma autora: "Los otros cuerpos disciplinados. Relaciones de género y estrategias de autocontrol del cuerpo femenino (primer tercio del siglo XX)", Arenal 14-1 (2007), pp. 79-108; y Aresti, Nerea: Masculinidades en tela de juicio, Madrid, Cátedra, 2010, pp. 103-104.

84 Significativamente, el grabado del pintor Aurelio Arteta recogido en el libro de Alejandro de la Sota Divagaciones de un transeúnte llevaba por título "La modistilla idealizada", desde una visión "realista" de las posibilidades de aquellas mujeres de alcanzar sus aspiraciones de ascenso social.

85 Cava Mesa, María Jesús: Alejandro de la Sota..., p. 29.

86 De la Sota, Alejandro: Divagaciones de un transeúnte..., p. 42.

87 De la Sota, Alejandro: Divagaciones de un transeúnte..., p. 43. 


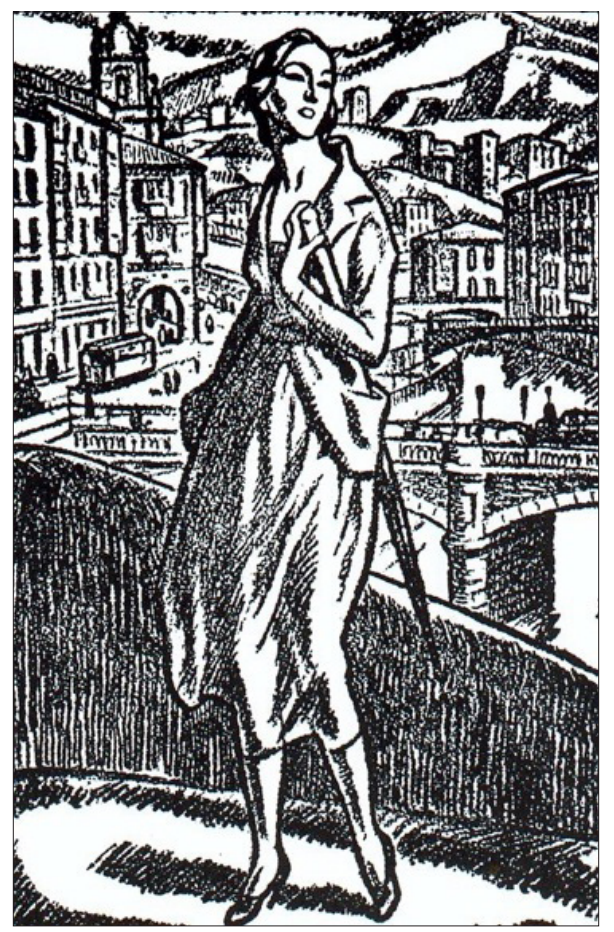

Imagen 1. "La modistilla idealizada", grabado de Aurelio Arteta, recogido en el libro Divagaciones de un transeúnte, de Alejandro de la Sota y Aburto, 1920.

Las "modistillas" transitaron así, en términos de género y de clase, por la frontera entre el orden y el desorden establecida por el gentleman, dandy y flâneur. En este y en otros muchos sentidos, Alejandro de la Sota no fue muy diferente a tantos jóvenes burgueses españoles y europeos que hicieron de su experiencia y de su identidad un ensayo de masculinidad moderna. Y en este ejercicio, el ejemplo inglés funcionó para él como referente constante, en un difícil equilibrio con el legado del pasado nacionalista. El trabajo, la elegante austeridad, el civismo y la cultura, el dominio civilizado del cuerpo y el deporte, y un respeto a las mujeres no reñido con la capacidad para atraer su atención fueron algunos de los elementos asociados a la figura del gentleman que Alejandro de la Sota quiso encarnar. Ciertos sectores del nacionalismo vasco encumbraron este ideal, lo adoptaron y vieron en él un modo de distanciarse de los modelos viriles asociados a España, particularmente los del caballero trasnochado y el del Don Juan improductivo, engalanado y desconsiderado hacia el sexo débil. Pocos nacionalistas expresaron este proyecto de contraste con tanta nitidez como Alejandro de la Sota. Pero más importante, y más allá del significativo ejemplo ofrecido por De la Sota, el nacionalismo vasco en su conjunto siguió encontrando en este contraste entre masculinidades un modo eficaz de afirmación identitaria frente a España. El último apartado hará referencia a este fenómeno a través del teatro propagandístico, una forma de discurso político que jugó un importante papel en la difusión de la doctrina nacionalista. 


\section{Reflexiones finales: la masculinidad de Andima}

Para finalizar este estudio, recapitularé importantes rasgos de la evolución de los ideales de masculinidad en el nacionalismo vasco a través de una obra de teatro que fue escrita y reescrita a lo largo del periodo analizado aquí. La obra en cuestión lleva por título Libe, un melodrama histórico ambientado en la batalla de Munguía de 1471 que enfrentó a Bizkaia con Castilla. Libe fue escrita originalmente por Sabino Arana en 1902 y publicada en $1903^{88}$. Años más tarde, en 1934, Manuel de la Sota, quien era hermano menor de Alejandro de la Sota, adaptó la obra para hacerla representable en un teatro ${ }^{89}$. Manuel de la Sota participaba entonces de una corriente del nacionalismo vasco muy diferente a la de su hermano, el PNV de Aberri, la tendencia más decididamente independentista. Manuel realizó una importante labor política en el ámbito del teatro propagandístico de la organización nacionalista, tarea en la que debemos enmarcar la dirección de la adaptación de Libe. Una mirada comparativa a las dos versiones de este relato de ficción, la Libe de Sabino Arana y la Libe recreada treintaiún años después, nos permitirá apreciar cambios reveladores en los arquetipos viriles presentes en el nacionalismo vasco, sin que ello implique, insisto, ni una evolución homogénea ni una ruptura con el pasado. La circunstancia familiar contribuyó indudablemente a acercar las visiones sobre la masculinidad de los hermanos Alejandro y Manuel, pero el análisis de la obra que planteamos transciende este aspecto biográfico afectando de lleno a productos culturales de gran operatividad política en el nacionalismo vasco de entreguerras y anterior incluso ${ }^{90}$.

En la obra original de Arana, la joven Libe, protagonista de la historia, sucumbió a la tentación del pecado enamorándose de un conde castellano, exponiendo con ello a su pueblo al peligro de la degeneración racial. Tras darse cuenta de la traición que suponía su amor por el conde Don Diego, Libe redimía su culpa dando la vida en el campo de batalla, convirtiéndose así en mártir heroína de la historia. Andima era el joven vasco enamorado de Libe y no correspondido por ella. Hemos de tener en cuenta que, aunque en el pensamiento misógino de Arana los hombres vascos constituían la expresión más acabada de la nación, también las mujeres vascas compartían estas cualidades viriles, los valores excelsos de la raza, sin que ello comprometiera su feminidad, menos valorada en sí misma en esta retórica que en el discurso nacionalista posterior ${ }^{91}$. La Libe de Arana establecía así una relación particular entre el sexo biológico y el género, una concepción que daba cabida a la mujer excepcional portadora de valores superiores -masculinos-, es decir, a la mujer que se elevaba sobre su condición femenina para convertirse en artífice de la victoria.

En la versión original de Libe encontramos que la imagen que trabaja cultural y políticamente no es tanto la de la "madre patria" como la de la "heroína viril", virgen inmaculada. Es la virtud de la castidad, no la maternidad, la que se sitúa en el centro

88 Arana, Sabino: Libe, Bilbao, Tipografía Universal, 1903; reeditado en el tomo III de O.C.

89 De la Sota, Manuel: "Libe. Unas consideraciones sobre su realización dramática", Euzkerea, 1, febrero de 1934.

90 Esta productividad política está relacionada particularmente con la capacidad de este teatro para generar emociones. Este aspecto ha sido destacado por Díaz Freire, José Javier: La República y el porvenir..., p. 213. Dicha función política tampoco pasó desapercibida a Sabino Arana, quien consideró el teatro un medio de propaganda. En Arana, Sabino, "El teatro como medio de propaganda", Bizkaitarra, 17 de febrero de 1895, O. C., tomo I, p. 471. Sobre esta cuestión, ver de la Granja, José Luis: "El teatro nacionalista vasco de Sabino Arana", en Pierre Bidart y Txomin Peillen (eds.): Eskual Antzertia. Le théâtre basque, Bayona, Université de Pau et des Pays de 1'Adour, 1987, pp. 19-37. Ver también De Pablo, Santiago y Mees, Ludger: El péndulo patriótico..., p. 10.

91 Aresti, Nerea: "De heroínas viriles...", pp. 284-285. 
del relato de Sabino Arana. La heroína Libe compartía los valores del monje guerrero sacrificado por su patria y los del pecador convertido tras la revelación, San Ignacio de Loyola. El melodrama concluía con una escena en la que una Libe moribunda era llevada por Dios para sí al cielo porque, se afirmaba, no había hombre digno de ella en la tierra ${ }^{92}$. Y en esta primera versión de la obra, Andima no llegaba a adquirir protagonismo, siendo Libe único objeto de atención y exaltación. Sí resultaron centrales y protagonistas, sin embargo, los valores masculinos de coraje y entrega patriótica encarnados, eso sí, por una mujer ${ }^{93}$.

En 1934, la adaptación de Libe realizada por Manuel de la Sota fue estrenada en Bilbao con gran éxito de público. El personaje de Libe había incorporado nuevos contenidos políticos y simbólicos en unos años en los que las emakumes, mujeres nacionalistas, veían en cierto modo reconocida su labor en el seno del movimiento, siempre como sujeto político sexuado y fundamentalmente en calidad de madres. Paralelamente, el nuevo personaje masculino de la obra nos remite a un arquetipo con muchas continuidades del pasado, pero visiblemente renovado. En la versión de los años treinta, los valores viriles ya no eran encarnados por una mujer, sino por un Andima situado en el centro de la narración. Según De la Sota, Andima era "el más bello y atrayente ejemplar de masculinidad" que pisaba escena en el drama ${ }^{94}$. Con él, ganaba también protagonismo en la trama el contraste entre la masculinidad patriótica de Andima y la del personaje castellano Don Diego, una oposición que servía para afirmar las virtudes de la raza vasca. La figura de Andima brillaba frente a la de su rival, el "ocioso y altanero señorito" que, con treinta años, no había hecho nada útil en toda su vida. El propio Manuel de la Sota admitió haberse tenido que desviar de la trayectoria de Sabino Arana para "resaltar alguno de los defectos de este personaje histórico".

El aludido personaje histórico, Don Diego, era un aristócrata castellano descrito como un donjuán trasnochado y estéril: "el prototipo de galán, que hace saltar de gozo el corazón de las mujeres". Aunque había nacido avispado, se afirmaba, "la prosapia de su linaje y su constante evocar las hazañas que acometieron sus antepasados (...) no le permiten ocuparse de los menesteres de este planeta" ${ }^{95}$. A diferencia de la crítica de Arana a personajes semejantes en sus novelas -recordemos la antes mencionada De fuera vendrán...- la realizada por Manuel de la Sota al castellano estaba centrada más en lo improductivo y obsoleto del modelo que en su carácter inmoral, en la mentira y adulterio. Por otro lado, frente al denostado Don Diego, el Andima imaginado por De la Sota era el "paladín de los anhelos de su pueblo, de aquel pueblo que tantas veces le había aclamado en las lides deportivas". Porque el joven resultaba ser un popular deportista, un pelotari.

Deseo destacar en este punto que, a pesar de que estos prototipos masculinos fueron concebidos para subrayar la especificidad de lo vasco frente a España, las conexiones con la evolución de los ideales de género en la sociedad española del

\footnotetext{
92 Arana, Sabino: O.C., tomo III, pp. 2035-2037.

93 Esto no significa que las tramas narrativas creadas por Sabino Arana respondieran siempre al mismo plan: en novelas como la comentada anteriormente De fuera vendrá..., Arana realizaba el contraste moral entre el pueblo español y el vasco a través de los personajes masculinos. Lo que llama la atención en Arana es el valor performativo del género y concretamente de la masculinidad, y su encarnación por una mujer.

94 Arana, Sabino (adapt. De la Sota, Manuel): Libe: Melodrama histórico, Bilbao, E. Verdes Achirica, 1934, [1903], p. 24.

95 De la Sota, Manuel: "Libe. Unas consideraciones...”, p. 47.
} 
momento eran claras. Y compartía con ella el deseo de reafirmación de la diferencia sexual en momentos de inestabilidad en las relaciones de género, es decir, tenía también un carácter reformador pero claramente normativo ${ }^{96}$. Hicimos referencia a esta conexión páginas atrás. La crítica del donjuanismo, la importancia otorgada al trabajo productivo y a la labor fecunda en el presente, los juicios sobre el deporte $\mathrm{y}$ el prestigio del gentleman, eran todos rasgos que estaban también presentes en el modelo de masculinidad reformada que había venido difundiéndose en medios políticos, intelectuales y científicos españoles. Incluso en cuestiones no centrales de este proyecto, como la relación del deporte con la virilidad, es difícil separar la visión defendida por Manuel De la Sota a través de su personaje Andima, de la teorización sobre el tema realizada por ideólogos como Gregorio Marañón. En opinión de este último, aunque saludable si se practicaba con mesura, el deporte podía suponer un peligro para la masculinidad, de forma semejante a lo que sucedía con el hacer estéril del Don Juan. El ejercicio físico podía llegar a ocupar, de forma capciosa y dañina, el lugar del trabajo en la vida de los jóvenes ${ }^{97}$. Esta idea fue compartida por Manuel de la Sota, quien vio necesario realizar la siguiente aclaración: "Mas no vaya a creerse -advirtió- que Andima era uno de esos seres del deporte -tan abundante en nuestros días- cuya única misión parece ser la de enamorar al bello sexo -débil no me atrevo a llamarlo ahora que los hombres lo somos tanto- como si se hallasen obligados a no ser más que inútiles exponentes de la esterilidad espiritual de los ejercicios físicos". "De esta manera", concluyó, "aquel sportman que era Andima-sportman en Inglaterra es sinónimo de caballero- de pronto se convierte en caudillo de un pueblo"98. El prestigio de la cultura anglosajona, percibida como quintaesencia del progreso y la modernidad, servía de nuevo como vehículo para la redefinición de los ideales de género.

Seguramente, los nacionalistas vascos en general, y particularmente los más conservadores, no buscaron inspiración en la literatura médica española por considerarla ajena, cuando no opuesta, a su cuerpo doctrinal. Esto no significa, como estamos comprobando, que tal influencia no existiera, sobre todo en los medios que, por su visión general de las cosas, podían resultar más receptivos a estos planteamientos. Pero incluso entre los más reacios, el criterio de utilidad política llegó a imponerse sobre una coherencia discursiva que, como bien demostró Sabino Arana, podía ser fácilmente sacrificada por las exigencias del contexto. El nacionalismo vasco estuvo más lejos de lo pretendido del modelo del gentleman y más cerca de lo reconocido de la evolución discursiva en el contexto español. Los puentes argumentales entre las retóricas políticas son así tan numerosos como impredecibles porque están construidos con materiales subjetivos y no pocas veces a base de forzadas maniobras de identificación y contraste. Volvemos de este modo al eje argumental de este estudio: la versatilidad de los conceptos y la capacidad de los sujetos para dotarles de significado contextual. Esta idea está relacionada con el carácter que Jacques Derrida

96 El choque que produjo en Manuel de la Sota el contacto con la sociedad estadounidense en sus años de exilio y su crítica de la excesiva autonomía y poder de las mujeres de aquel país, excesivamente liberal en su opinión, son muestra también de los estrechos límites de su visión de las relaciones de género. González-Allende, Iker, "Estados Unidos como patria de redención: el exilio del nacionalismo vasco en Yanqui Hirsitus, de Manuel de la Sota", Cuadernos de Aldeeu, 30 (2016), pp. 13-34, en p. 19.

97 Decía Gregorio Marañón que "el deportista es al trabajador lo que la cortesana a la madre”. Marañón, Gregorio: Tres ensayos sobre la vida sexual, Madrid, Biblioteca Nueva, 1926, p. 57.

98 De la Sota, Manuel: "Libe. Unas consideraciones...,", p. 50. Esta cita y las anteriores en el párrafo. 
denominaría iterativo y citacional de los discursos ${ }^{99}$, los cuales, siempre inestables, podrían ser considerados más bien acontecimientos discursivos. A lo largo de estas páginas hemos visto cómo esta precariedad afecta al análisis del significado de la masculinidad y al propio concepto de civilización.

Un último ejemplo, de la mano del nacionalista vasco José Ramón de Ametzola, ilustrará esta idea de versatilidad de forma pintoresca. Desde las páginas de Euzkadi, Ametzola utilizó el trabajo de Marañón sobre Henri-Frédéric Amiel para destacar las virtudes de Sabino Arana en el aniversario de su muerte. Para Gregorio Marañón, el tímido Amiel era un prototipo viril completo, acabado, el opuesto al Don Juan afeminado e "indiferenciado". Ametzola partió de esta idea para equiparar Amiel y Arana: "El primero busca, según Marañón, a través del sexo, a la mujer única, a la superdiferenciada. Sabino busca, a través del patriotismo, al vasco íntegro [...]"100. Tras el forzado paralelismo, el análisis de Marañón servía para elevar la figura del "Maestro" sobre el filósofo suizo. Y es que frente a la generosidad y entrega a las demás características de Arana, Amiel era avaricioso e introvertido en extremo. La precariedad de las identificaciones y contrastes no requiere en este caso mayor comentario. Ametzola finalizó su artículo de homenaje con un agradecimiento al "forjador de la orientación de nuestros destinos", unos destinos que habrían quedado para siempre marcados en "las entrañas de la patria, de cara al Norte de los vientos de la libertad y la cultura"101. La mirada, una vez más, se dirigió al mar, al norte de progreso y civilización.

99 Derrida, Jacques: "Firma, acontecimiento y contexto", en Márgenes de la filosofia, Madrid, Cátedra, 1989, pp. 361-367.

100 Ametzola, José Ramón de: “Personalidad de Sabino de Arana-Goiri”, Euzkadi, 25 de noviembre de 1933, p. 7.

101 Ametzola, José Ramón de: "Personalidad de Sabino...”. 